\author{
Kamila Rezmer-Płotka \\ Nicolaus Copernicus University (Poland) \\ e-mail: kamila.rezmer@onet.pl \\ ORCID: https://orcid.org/0000-0002-1458-5076
}

\title{
Restrictions of Freedom of Press as an Indicator of Neo-Militant Democracy in Lithuania ${ }^{1}$
}

\begin{abstract}
For the first time, Karl Loewenstein had used the category of militant democracy concerning the Weimar Republic. Although the world's situation has changed, the process of political systems taking over non-democratic regimes' characteristics is still visible. Among the indicators that can testify to becoming militant democracy, the restriction of freedom of the press is distinguished. This article attempts to analyze the dynamics of this process in Lithuania based on the Freedom House reports. The research question formulated is: What restrictions on the press's freedom in Lithuania occurred in the period? The hypothesis is: In 2008-2019 in Lithuania, there has been a regular restriction on the freedom of the press, which may indicate a progressive process of militant democracy. Results: The hypothesis has been partially verified positively. During the period considered, there were regular restrictions on the freedom of the press but were justified mainly by circumstances, or immediate counter-action was taken.
\end{abstract}

Keywords: militant democracy, freedom of the press, Lithuania, Freedom House

\section{Introduction}

According to the Press Freedom Index, Lithuania is regarded as one of the countries in which the freedom of the press is unlikely to be seriously threatened (Lithuania - Press freedom index, 2020). Despite this, information about possible violations appears every few years. It is precisely these violations and restrictions that can testify to the progressive process of militant democracy, and thus the use of legal means to restrict individual democratic freedom to defend democracy. For this reason, it is essential to examine the countries recognized

\footnotetext{
${ }^{1}$ This paper is a result of the research project Contentious Politics and Neo-Militant Democracy. It was financially supported by the National Science Centre, Poland [grant number 2018/31/B/HS5/01410].
} 
as democracies in terms of the constraints spread over time so that the dynamics of these regimes' acquisition of the characteristics of non-democratic systems can be parameters

The article focuses on one of the countries where the political transformation took place and is a EU member, namely Lithuania. The research question in the article is: What restrictions on the freedom of the press in Lithuania occurred in the period? The hypothesis is: In 2008-2019 in Lithuania, there has been a regular restriction on the freedom of the press, which may indicate a progressive process of militant democracy. A qualitative analysis of Freedom House reports was carried out to verify the research hypothesis and answer the research question. It is an American non-profit organization that investigates democracy and respect for freedom in the world. The organization describes itself on its website as follows: "Freedom House works to defend human rights and civil liberties. We act as a catalyst for freedom through a combination of analysis, advocacy, and action" (Freedom House, 2020). For this reason, it was selected as an appropriate database of reports on the matter covered in the article. The time caesura adopted in the study is $2008-2019$, as the progressive process of militant democracy began to be seen after the severe financial crisis of 2008 . The end date results from natural factors: particularly the occurrence of a pandemic of coronavirus in 2020 .

\section{Category of Neo-Militant Democracy}

For the first time, the militant democracy category appeared in Karl Loewenstein's works, who was looking for the reasons for the Weimar Republic's failure in the fight against Nazism. Although the world's situation has changed, the process of political systems taking over non-democratic regimes' characteristics is still visible. Militant democracy means a political system in which parliament (Marszałek-Kawa, 2019) and the judiciary are equipped with legal means to restrict individual democratic freedom to defend democracy, and therefore its survival, against those who are considered its internal but also external enemies (Bäcker, Rak, 2019, p. 68).

The category of militant democracy can also be successfully applied today after being modified and adapted to the current conditions. Joanna Rak points out that such a modification presupposes the classic approach's essential features but considers the characteristics relevant to post-2008 processes. In this way, regimes take over the features of neo-militant democracy, ignoring those that have already lost their relevance (Rak, 2020,p. 62). According to the definition proposed by the researcher, neo-militant democracy defends itself against all kinds of non-systemic political opposition by restricting individual freedom to protect itself from the threat of being changed by legal means (Rak, 2020, p. 65).

Nowadays, among the restrictions specific to neo-militant democracy are: restrictions on the freedom of the press (Capoccia 2005, pp. 57-61), religious freedom (Müller 2012, p. 1119), assemblies (Mareš, 2012, p. 34), speech (Ijabs, 2016, 289; Mareš 2012, p. 36), association (Mareš, 2012, p. 36), active voting rights (Ijabs, 2016, p. 289) and passive (Ijabs 
2016, p. 289), related to the organization of referendums (Ijabs, 2016, p. 288), regulations on terrorism and counteracting this phenomenon (Macklem, 2006, pp.488-489), restrictions in the registration and activities of political parties (Mareš, 2012, p. 36), in the acquisition of citizenship (Ijabs, 2016, p. 289), in access to public employment (Mareš, 2012, p. 36), anti-extremism (Capoccia, 2005, pp. 57-61; Sajó, 2005, p. 2280), freedom of movement (Sajó, 2005, p. 2280), as well as judicial independence (Kirshner, 2014, p. 21). Of all the listed indicators, this article selected the first of them: freedom of the press, because it seems that in this case, the most severe violations occur. Firstly, the flow of information is so dynamic today that it is sometimes difficult to distinguish between fake news and real stories, which may cause enormous abuses. Secondly, one can easily justify the restriction of the freedom of the press on political grounds, for example, by political correctness or social harm. Thirdly, it is becoming increasingly difficult to distinguish between censorship and security, and other considerations. It should be emphasized that taking into account the restrictions in all these areas would make it possible to determine more precisely the likelihood that Lithuania becomes a militant democracy or not. However, it is much more interesting to look at one of the areas over a long period, allowing for a much more accurate analysis.

\section{Freedom of the Press in Lithuania}

In the 2008 and 2009 reports, Freedom House did not show any severe restrictions on freedom of the press (Freedom House, 2008; Freedom House, 2009).

A 2010 report only pointed out that the Lithuanian press suffers from written codes of conduct or inadequate standards for transparency of ownership (Freedom House, 2010).

The following year is still a topical issue of inadequate standards for transparency of ownership, and it was pointed out that in March 2010, the Law on the Protection of Minors came into effect, which referred to the prohibition on the supply of copyright material to minors (Freedom House, 2011). There has also been news that citizens have been prosecuted in recent years for positing hate-inciting content online (Freedom House, 2011).

A 2012 report raised the issue of inadequate standards for transparency of ownership and the mentioned Law on the Protection of Minors in 2010. This time it was pointed out that it was not only about limiting harmful content but also about "denigrates family values" (Freedom House, 2012), including condoning same-sex marriage. The cases of two journalists brought to justice (Freedom House, 2012) were also cited.

In 2013, the case of a journalist with whom a documentary about President Dalia Grybauskaite was terminated was cited, saying that she had violated the station's ethical standards. The second case concerned a Vilnius journalist whose court found guilty of denying Soviet aggression against Lithuania, the remaining issue of inadequate standards for transparency of ownership, and doubts related to the 2010 Law banning the publication of material deemed harmful to minors (Freedom House, 2013). 
The 2014 report cited the example of a person fined for showing communist symbols (a portrait of Stalin) at a May ceremony commemorating the Soviet victory over Nazi Germany. It was then concluded that the provision prohibiting the use of communist symbols at mass gatherings was violated in this way. At the end of the year, Lithuania's Special Investigation Service searched the headquarters of Lithuania’s largest news agency, interrogated journalists, and confiscated several computers. It meant that there was a breach of journalistic secrecy by the service. As in previous years, inadequate standards for transparency of ownership and doubts related to the Freedom House Act 2010 remained topical.

The following year is a repeated problem of "inadequate standards for transparency of ownership, and political parties are banned from directly owning news media outlets" (Freedom House, 2015). However, the most severe shortcomings were identified in connection with the Lithuanian STT and Baltic News Service's attempts to disclose its sources in connection with information about Russian officials' plans to launch a misinformation campaign about Grybauskaite. However, the Provincial Administrative Court ruled that eavesdropping on BNS employees was unlawful. In July, amendments to the Law on Provision of Information to the Public and the Code of Criminal Procedure were signed. As a result, violations of the freedom of the press or individual freedom are only possible for significant public interest cases. Subsequent amendments introduced penalties for "media outlets that spread war propaganda, urge changes in the constitutional order, or challenge the country's sovereignty" (Freedom House, 2015). At the Lithuanian Radio and Television Commission's request, a ban on broadcasting Russian television channels for three months (Freedom House, 2015) was issued.

In 2016, it was pointed out that many politicians still control news media outlets despite the ban on political parties having their news media. In some instances, penalties for the media were foreseen, based on amendments to the Law on Public Information approved in May 2015. Moreover, parliament has made changes to the media self-regulation body, i.e., only media representatives could be part of it. Some Russian television channels have been fined or banned from temporarily broadcasting their broadcasts. Moreover, this was supported by the European Commission. By contrast, after adopting the Law on the Protection of Minors against the Detrimental Effect of Public Information in 2010, there have been several cases in which public information about rights for LGBT people has been restricted.

As for 2017, it was reported that "This country report has been abridged for Freedom in the World 2017. For background information on political rights and civil liberties in Lithuania, see Freedom in the World 2016" (Freedom House, 2017). It means that there have been no major restrictions and significant changes. Probably, there were the same difficulties as in the previous year.

In 2018, there was only laconic information that, despite general respect for the freedom of speech and the press, some media outlets attempt to use their position to influence political processes, and that local outlets are usually financially dependent on the local government (Freedom House, 2018). It meant that there were no more severe restrictions 
on the freedom of the press. However, the persons responsible for providing information have tried to influence politicians' decisions, so there was a phenomenon of lobbying. It is also interesting to see the second phenomenon indicated, namely the dependence of local outlets on local government, which may mean that the transmission of information could in no small extent be adapted under the governing bodies in the territory concerned. Otherwise, funding would be reduced or completely stopped. The same information also appears in 2019 (Freedom House, 2019).

\section{Conclusions}

In Lithuania, in addition to several individual incidents concerning restrictions on the freedom of the press, although there is a ban on political parties owning news media outlets, there were also repeated restrictions on inadequate standards for transparency of ownership and the control of the media by politicians. It would be necessary to point to attempts taken by the Lithuanian STT and Baltic News Service to disclose its sources and eavesdropping by former and current employees' services from more severe restrictions. However, what is important is that a judgment has been delivered in this case, stating that eavesdropping was unlawful. In recent years, it has been signaled that some owners of media outlets attempt to use their position to influence political processes and local outlets are usually financially dependent on the local government. However, despite the violations and limitations pointed out in Freedom House reports, the Press Freedom Index can see a steady increase in value, which means respecting the individual's rights and freedom in terms of speech and the press. Despite a few slight fluctuations, they did not affect the whole perception of Lithuania.

On the one hand, the restrictions imposed on Russian channels were welcomed by the European Commission, as the problematic situation on the Ukraine-Russia line took place at that time. Thus, the hypothesis - In 2008-2019 in Lithuania, there has been a regular restriction on the freedom of the press, which may indicate a progressive process of militant democracy - has been partially verified in the affirmative.

During the period considered, there were regular restrictions, but they did not blatantly affect the freedom of the press. Moreover, circumstances, such as the situation related to Russian broadcasts, justified some of the limitations. The competent court decided the case of eavesdropping by the service. Lithuania also gained higher and higher rankings concerning the freedom of the press. On the other hand, regular restrictions, including some repeated, can manifest a relatively slow but tangible process of becoming militant democracy over such a long period. It may also mean that even a regular restriction of individual freedom does not always lead to the regime acquiring non-democratic systems' characteristics. It seems much more important to look for reasons for restrictions or analyze the most important authorities in the country when a constraint is introduced. On the example of Lithuania, it can be observed that Lithuania respects freedom of the press at a high level, as the Press 
Freedom Index (Knoema, 2020) also points out. Still, even in such a country, it is impossible to avoid serious infringements altogether.

\section{References:}

Bäcker, R., Rak, J. (2019). “Trajektoria trwania opancerzonych demokracji”. Studia nad Autorytaryzmem i Totalitaryzmem, 41(3), 63-82.

Capoccia, G. (2005). Defending Democracy Reactions to Extremism in Interwar Europe. BaltimoreLondon.

Freedom House. (2008). “Freedom in the world 2008 - Lithuania”. Retrieved from: https://www.refworld. org/docid/487ca222b.html.

Freedom House. (2009). “Freedom in the world 2009 - Lithuania”. Retrieved from: https://www.refworld. org/docid/4a6452a3c.html.

Freedom House. (2010)."Freedom in the world 2010 - Lithuania”. Retrieved from: https://www.refworld. org/docid/4c23123f28.html.

Freedom House. (2011)."Freedom in the world 2011 - Lithuania". Retrieved from: https://www.refworld. org/docid/4elefebcla.html.

Freedom House. (2012). “Freedom in the world 2012 - Lithuania”. Retrieved from: https://www.refworld. org/docid/5028efa932.html.

Freedom House. (2013). “Freedom in the world 2013 - Lithuania”. Retrieved from: https://www.refworld. org/docid/5171048718.html.

Freedom House. (2014). “Freedom in the world 2014 - Lithuania”. Retrieved from: https://www.refworld. org/docid/53b2b8bb12.html.

Freedom House. (2015). "Freedom in the world 2015 - Lithuania”. Retrieved from: https://www.refworld. org/docid/55d444e06.html.

Freedom House. (2016)."Freedom in the world 2016 - Lithuania". Retrieved from: https://www.refworld. org/docid/57bc4f346.html.

Freedom House. (2017). “Freedom in the world 2017 - Lithuania”. Retrieved from: https://freedomhouse. org/country/lithuania/freedom-world/2017.

Freedom House. (2018). “Freedom in the world 2018 - Lithuania". Retrieved from: https://www.refworld. org/docid/5b7bcc6fa.html.

Freedom House. (2019). “Freedom in the world 2019 - Lithuania”. Retrieved from: https://freedomhouse. org/country/lithuania/freedom-world/2019.

Freedom House. (2020). “Our issues". Retrieved from: https://freedomhouse.org/issues.

Ijabs, I. (2016). "After the Referendum: Militant Democracy and Nation-Building in Latvia". East European Politics and Societies and Cultures, 2(30), 288-314.

Kirshner, A. (2014). A Theory of Militant Democracy: The Ethics of Combatting Political Extremism. New Haven and London: Yale University Press.

Knoema (2020)."Lithuania - Press freedom index". Retrieved from: https://knoema.com/atlas/Lithuania/ Press-freedom-index.

Macklem, P. (2006). “Militant Democracy, Legal Pluralism, and the Paradox of Self-determination”. International Journal of Constitutional Law, 3(4), 488-516. 
Mareš, M. (2012). “Czech Militant Democracy in Action: Dissolution of the Workers' Party and the Wider Context of This Act”. East European Politics and Societies, 33(26), 33-55.

Marszałek-Kawa, J. (2019). The Institutional Position and Functions of the Sejm of the Republic of Poland after the Accession to the European Union. Odessa: Helvetica Publishing House.

Müller, J.-W. (2012). “Militant Democracy”. In M. Rosenfeld \& A. Sajó (Eds.), The Oxford Handbook of Comparative Constitutional Law (1119). New York: Oxford University Press. DOI: https://doi.org/ oxfordhb/9780199578610.013.0062.

Rak, J. (2020). “Conceptualizing the Theoretical Category of Neo-militant Democracy: The Case of Hungary”. Polish Political Science Yearbook, 49(2), 61-70.

Sajó, A. (2005). “From Militant Democracy to the Preventive State”. Cardozo Law, 5(27), 2255-2294. 